\title{
Phytochemical analysis and antimicrobial and antioxidant activities of Celosia argentea leaves
}

Análise fitoquímica e atividades antimicrobiana e antioxidante de folhas de Celosia argentea

G. J. da Silva Neto ${ }^{1}$; E. J. de Santana ${ }^{1}$; A. R. de Sena ${ }^{1}$; B. A. de Morais ${ }^{1}$; M. I. F. de Araújo ${ }^{2}$; P. P. S. Barbosa ${ }^{3}$; M. R. F. de Mello' ${ }^{1}$ T. C. C. Leite ${ }^{1}$; E. F. O. Borba ${ }^{2}$

${ }^{1}$ Federal Institute of Education, Science and Technology of Pernambuco, 55560-000, Barreiros-PE, Brazil.

${ }^{2}$ Federal University of Pernambuco, 50670-901, Recife-PE, Brazil.

${ }^{3}$ Federal University of Paraiba, 58051-900, PB, Brazil

*paulabio05@hotmail.com

(Received on May 25, 2021; accepted on September 13, 2021)

This study performed the phytochemical screening and bioactivity of Celosia argentea leaves. The phytochemical profile of hexane (Hex), ethyl acetate (AcOEt) and methanolic $(\mathrm{MeOH})$ extracts of $C$. argentea leaves was observed by Thin Layer Chromatography and spectrophotometric analysis. In the susceptibility test, the disk-diffusion technique was performed. Minimum Inhibitory Concentration (MIC) was assessed by microdilution. Minimum Microbic Concentration (MMC) was determined in the extracts which presented MIC. Antioxidant activities were measured using 2,2-diphenyl-1-picril-hidrazil (DPPH), determination of reducing power and total antioxidant capacity (TAC). The results showed a higher content of phenolic compounds (252.02 $\pm 0.02 \mathrm{mg} \mathrm{GAE} / \mathrm{g})$ in the extract AcOEt, and of tannins (103.72 \pm $0.004 \mathrm{mg} / \mathrm{EAT} / \mathrm{g}$ ) in $\mathrm{MeOH}$; this was effective against Micrococcus luteus (inhibition of $24.7 \pm 0.6 \mathrm{~mm}$ ). MIC and CMM of the AcOEt for M. luteus were 0.06 and $0.25 \mathrm{mg} / \mathrm{mL}$, respectively. The $\mathrm{MeOH}$ extract eliminated $70.4 \pm 0.03 \%$ of DPPH radical, whereas AcOEt had greater reducing power $(289.23 \pm 0.05 \mathrm{mg}$ $\mathrm{AA} / \mathrm{g}$ ) and $\mathrm{TAC}$ at a concentration of $250 \mu \mathrm{g} / \mathrm{mL}(89.6 \%)$. This study revealed that $C$. argentea has phytochemicals with bactericidal and fungicidal potential, in addition to elevated antioxidant power.

Key words: antimicrobial, antioxidant, bioactivity.

Este estudo realizou a triagem fitoquímica e bioatividade das folhas Celosia argentea. O perfil fitoquímico dos extratos hexano (Hex), acetato de etila (AcOEt) e metanólico $(\mathrm{MeOH})$ das folhas de $C$. argentea foi avaliado por cromatografia em camada delgada e espectrofotometria. Para o teste de suscetibilidade, foi realizada a técnica de disco-difusão; a Concentração Inibitória Mínima (CIM) foi avaliada por microdiluição, e a Concentração Microbiana Mínima (CMM) foi determinada nos extratos que apresentaram CIM. A atividade antioxidante foi caracterizada através da verificação da capacidade de sequestro do 2,2-difenil-1-picril-hidrazil (DPPH), da determinação do poder redutor e da capacidade antioxidante total (TAC). Os resultados mostraram maior teor de compostos fenólicos $(252,02 \pm 0,02 \mathrm{mg}$ $\mathrm{GAE} / \mathrm{g}$ ) no extrato AcOEt, e de taninos $(103,72 \pm 0,004 \mathrm{mg} \mathrm{EAT} / \mathrm{g})$ no $\mathrm{MeOH}$, o qual foi eficaz contra Micrococcus luteus (inibição de 24,7 $\pm 0,6 \mathrm{~mm}$ ). A MIC e a CMM do AcOEt para a cepa mencionada foram 0,06 e $0,25 \mathrm{mg} / \mathrm{mL}$, respectivamente. $\mathrm{O}$ extrato de $\mathrm{MeOH}$ eliminou 70,4 $\pm 0,03 \%$ do radical $\mathrm{DPPH}$, enquanto o AcOEt apresentou maior poder redutor $(289,23 \pm 0,05 \mathrm{mg} \mathrm{AA} / \mathrm{g})$ e o TAC na concentração de $250 \mu \mathrm{g} / \mathrm{mL}(89,6 \%)$. Este estudo revelou que as folhas de C. argentea possui fitoquímicos com potencial bactericida e fungicida, além de elevado poder antioxidante.

Palavras-chave: antimicrobiano, antioxidante, bioatividade.

\section{INTRODUCTION}

The use of plants in treating diseases is old as the human being and has enabled the discovery of several herbal medicines [1]. The reason for its use is the arsenal of chemical compounds with therapeutic value, in particular the secondary metabolites, responsible for defense and protection of vegetables, but with physiological action in the human body as antioxidant and antimicrobial, added to its low toxicity when compared to synthetic drugs [2]. Therefore, new plant species and their bioactive constituents have been constantly investigated.

Among the various medicinal plants, Celosia, whose representatives are used as food supplement to combat micronutrient deficiency, stands out [3]. Native of African and Asian 
continents and belonging to the family Amaranthaceae A. Juss, the genus comprises 60 species distributed in areas of tropical and subtropical climates. Among those introduced in the Brazilian territory is Celosia argentea Linn, an herbaceous highly consumed due to its high nutritional value and used as an ornamental plant $[4,5]$. In traditional medicine, it is applied to treat diabetes, inflammation, fever, gastroenteritis, and leukorrhea [6].

Experimental studies with $C$. argentea indicated protective activity of the seeds in eye and liver lesions, and antibacterial action of the leaves, effects that can be favored by primary metabolites, such as carbohydrates, lipids, amino acids, and peptides, and secondary metabolites, such as phenols, phenolic acids, flavonoids, terpenes and alkaloids [7-9].

In this context, the objective of work was to evaluate the phytochemical profile of different extracts of $C$. argentea leaves and their antimicrobial and antioxidant properties to add therapeutic value to the species.

\section{MATERIAL AND METHODS}

\subsection{Plant material}

C. argentea samples were collected in Jaqueira (Alagoas, Brazil), by noon in summer, identified and deposited in the herbarium of the Agronomic Institute of Pernambuco (IPA) by curator, the botanist Rita de Cássia Pereira (specimen voucher 92.965; SisGen registration $n^{\circ}$ A430904).

\subsection{Microorganisms}

The tests were performed with four Gram-positive bacterial: Staphylococcus aureus (UFPEDA 01), Micrococcus luteus (UFPEDA 06), Bacillus subtilis (UFPEDA 16) and Enterococcus faecalis (UFPEDA 138); three Gram-negative: Escherichia coli (UFPEDA 224), Serratia marcescens (UFPEDA 398) and Pseudomonas aeruginosa (UFPEDA 39); with acidresistant alcohol strain: Mycobacterium smegmatis (UFPEDA 71); and with one fungal strain: Candida albicans (UFPEDA 1007). All microorganisms were obtained from the Department of Antibiotics (DA) laboratory of the Federal University of Pernambuco (UFPE).

\subsection{Inoculum}

The bacterial and fungal suspensions were grown on Nutrient (NA) and Sabouraud Dextrose (SDA) Agar, respectively. Bacterial strains were incubated at $35 \pm 2{ }^{\circ} \mathrm{C}$ for $24 \mathrm{~h}$, and fungal at $35 \pm 2{ }^{\circ} \mathrm{C}$ for $24-48 \mathrm{~h}$. After incubation, approximately $4-5$ colonies were transferred to test tubes containing $5.0 \mathrm{~mL}$ of sterile saline $(0.85 \% \mathrm{NaCl})$. The resulting suspensions were vortexed for $15 \mathrm{~s}$ (Fanem Ltda, Guarulhos, SP, Brazil). The final turbidity of inoculum was normalized with a suspension of barium sulfate ( 0.5 tube on the McFarland scale). The final concentration obtained was $1-5 \times 10^{8}$ colony-forming units per milliliter $(\mathrm{CFU} / \mathrm{mL})$ for bacteria, and $1-5 \times 10^{6}(\mathrm{CFU} / \mathrm{mL})$ for the fungal strain $[10,11]$.

\subsection{Preparation of crude extract}

The $C$. argentea leaves were dried at $37{ }^{\circ} \mathrm{C}$ in an oven with controlled temperature and constant renewal of air for four days, triturated with a knife mill, and then macerated with hexane, ethyl acetate $(\mathrm{AcOEt})$ or methanol $(\mathrm{MeOH})$ at a 1:10 (w/v) for seven days at room temperature. The mass obtained from each extract was $2 \mathrm{~g}, 3 \mathrm{~g}$ and $10 \mathrm{~g}$, respectively. 


\subsection{Phytochemical profile by Thin Layer Chromatography (TLC)}

The hexane, AcOEt, and $\mathrm{MeOH}$ extracts of $C$. argentea leaves were qualitatively analyzed for phytochemical composition by Thin Layer Chromatography (TLC), using silica gel plates pre-coated by $\mathrm{F}_{254}$ as stationary phase [12, 13], and as mobile phase, $5 \mathrm{mg} / \mathrm{mL}$ of each extract was applied concentrations of Hex: AcOEt (7:3), Hex: AcOEt (6:4), and Hex:AcOEt:MeOH (2:6:2). The eluents were used to fraction the compounds present in the extracts. Standard developers were co-chromatographed for each class of phytochemical constituent. The developed plates were observed in UV-Vis at $254 \mathrm{~nm}$ and $356 \mathrm{~nm}$.

\subsection{Total Phenolic Content}

To quantify total phenols, in a test tube, $0.2 \mathrm{~mL}$ of the extract at a concentration of 500 $\mu \mathrm{m} / \mathrm{ml}, 500 \mu \mathrm{L}$ of the $10 \%$ (v/v) Folin-Ciocalteu reagent, $1 \mathrm{~mL}$ of the sodium carbonate solution $\left(\mathrm{Na}_{2} \mathrm{CO}_{3}\right)$ at $7{ }^{\circ} \mathrm{C}, 5 \%(\mathrm{w} / \mathrm{v})$ and $3 \mathrm{~mL}$ of distilled water. The samples were incubated at room temperature for $30 \mathrm{~min}$, without light interference, then the absorbance spectrum of the extracts was analyzed at $760 \mathrm{~nm}$. The absorbance values of gallic acid determined the standard curve at concentrations of $25,50,75,100,125$, and $150 \mu \mathrm{g} / \mathrm{mL}$. The total phenol content is expressed as milligrams of Gallic Acid Equivalent per gram of extract (mg GAE/g) [14].

\subsection{Total flavonoid content}

To determine the flavonoid content, $1 \mathrm{~mL}$ of each extract, $4 \mathrm{~mL}$ of distilled water, and 300 $\mu \mathrm{L}$ of $25 \%$ sodium nitrite $\left(\mathrm{NaNO}_{2}\right)$ were added. After $5 \mathrm{~min}, 300 \mu \mathrm{L}$ of $10 \%$ aluminum chloride $\left(\mathrm{AlCl}_{3}\right)$ was added to the solution, and the system was incubated for $1 \mathrm{~min}$. Then $2 \mathrm{~mL}$ of sodium hydroxide solution $(\mathrm{NaOH}) 1 \mathrm{~mol} / \mathrm{L}$ and $2.4 \mathrm{~mL}$ of distilled water were added. After stirring, the absorbances were checked at $510 \mathrm{~nm}$. The content of total flavonoids was determined by interpolating the samples' absorbance against a calibration curve constructed with a standard rutin solution and expressed as milligrams of rutin equivalent per gram sample (mg $\mathrm{RE} / \mathrm{g})$. To prepare the standard curve, a mixture of rutin $(50,250,300,400$, and $500 \mu \mathrm{g} / \mathrm{mL}$ ), distilled water $(4 \mathrm{~mL})$, and sodium nitrite $\left(\mathrm{NaNO}_{2}\right)$ at $25 \%(300 \mu \mathrm{L})$ was produced and incubated for $5 \mathrm{~min}$, then $300 \mu \mathrm{L}$ of $10 \% \mathrm{AlCl}_{3}$ was added for $1 \mathrm{~min}$, then $2 \mathrm{~mL}$ of $1 \mathrm{~mol} / \mathrm{L}$ sodium hydroxide solution $(\mathrm{NaOH})$ and $2.4 \mathrm{~mL}$ of distilled water were added, remaining under constant agitation for $5 \mathrm{~min}[15]$.

\subsection{Total tannin content}

To determine total tannin content, $500 \mu \mathrm{L}$ of each extract was incubated under constant shaking for $3 \mathrm{~min}$ with $2.5 \mathrm{~mL}$ of the reagent Folin-Ciocalteu (10\%). Then, $2 \mathrm{~mL}$ of $20 \%$ sodium carbonate solution $\left(\mathrm{Na}_{2} \mathrm{CO}_{3}\right)$ were added, and the mixture remained for $2 \mathrm{~h}$ in the dark. Readings were taken at $725 \mathrm{~nm}$.

For analysis of the standard curve, the sample was replaced by tannic acid in different concentrations, and the process continued as previously mentioned $(125,250,700,800,1750$, and $2000 \mu \mathrm{g} / \mathrm{mL}$ ). The total tannin content was determined by interpolating the absorbance of the sample against the standard tannic acid solution's calibration curve, and the results were expressed in milligrams of tannic acid equivalent per gram of sample (mg TAE/g) [16].

\subsection{Diphenyl-1-picrilhidrazil (DPPH) sequestering activity}

The ability of $C$. argentea leaves to eliminate the free DPPH radical was determined according to Fayaz et al. (2019) [20]. The DPPH radical (0.004\%) prepared in ethanol was mixed in different concentrations from the $C$. argentea leaves stock solution $(1.0$ to $5.0 \mathrm{mg} / \mathrm{mL})$. The systems were shaken and left in the dark at room temperature for $30 \mathrm{~min}$; and activity was verified at $517 \mathrm{~nm}$. All tests were performed in triplicate. Ascorbic acid was used as a standard 
and the percentage of sequestering activity (\% AS) of the DPPH radical was calculated using the equation:

$$
\% \text { AS }=100 x(\text { ABScontrol }- \text { ABSsample }) / \text { ABScontrol }
$$

Where: $\mathrm{Abs}_{\text {control }}$ is the absorbance of DPPH + ethanol, and $\mathrm{Abs}_{\text {sample }}$ is the absorbance of DPPH + sample (sample or standard). The antiradical efficiency was established using linear regression analysis and the results were expressed through the concentration of the sample necessary to obtain half of the sequestering activity of the DPPH radicals plus or minus the standard error of the mean $\left(\mathrm{EC}_{50} \pm \mathrm{SEM}\right)$.

\subsection{Determination of reducing power}

The reducing power of $C$. argentea leaves was verified by the method of Waterman and Mole (1994) [14], whereby $100 \mu \mathrm{L}$ of the test solutions (crude extracts and fractions) diluted in methanol were used, with a final concentration of $0.5 \mathrm{mg} / \mathrm{mL}$. Afterwards, $8.5 \mathrm{~mL}$ of distilled water and $1.0 \mathrm{~mL}$ of the $0.1 \mathrm{~mol} / \mathrm{L} \mathrm{FeCl}_{3}$ were added and incubated for $3 \mathrm{~min}$. After the time, $1.0 \mathrm{~mL}$ of $0.08 \mathrm{~mol} / \mathrm{L}$ potassium ferricyanide was added and left to stand for $15 \mathrm{~min}$. Finally, the absorbance was measured at $720 \mathrm{~nm}$.

The analysis was performed in triplicate. The calibration curve was formed using standard solutions of ascorbic acid in concentrations of 0.025 to $0.5 \mathrm{mg} / \mathrm{mL}\left(\mathrm{y}=0.0029 \mathrm{x}-0.0055 ; \mathrm{R}^{2}=\right.$ 0.9917). The reducing power of the samples was expressed in $\mathrm{mg}$ of ascorbic acid (AA) per gram of sample.

\subsection{Total Antioxidant Capacity Test (TAC)}

The total antioxidant capacity of $C$. argentea extracts was evaluated using the phosphomolybdenum method [21]. Briefly, $0.3 \mathrm{~mL}$ of different concentration $(125,250$ and 500 $\mu \mathrm{g} / \mathrm{mL})$ of the extracts were combined with $3 \mathrm{~mL}$ of the reactive solution $(0.6 \mathrm{~mol} / \mathrm{L}$ sulfuric acid, $28 \mathrm{mmol} / \mathrm{L}$ sodium phosphate, and $4 \mathrm{mmol} / \mathrm{L}$ ammonium molybdate). The reaction mixture was placed in test tubes and incubated at $95{ }^{\circ} \mathrm{C}$ for $90 \mathrm{~min}$. The absorbance of the solution was measured at $695 \mathrm{~nm}$ against a blank $(0.3 \mathrm{~mL}$ of distilled water and $3 \mathrm{~mL}$ of the reagent). For the calculation, the rutin standard was considered as $100 \%$ of antioxidant activity, using the equation:

$$
\% \text { antioxidant activity }=\text { ABSsample }- \text { ABSblank x 100/ABSrutin }- \text { ABSblank }
$$

Where: $\mathrm{ABS}_{\text {sample }}$ is the absorbance of sample, and $\mathrm{ABS}_{\text {blank }}$ is the absorbance of blank, and $\mathrm{ABS}_{\text {rutin }}$ is the absorbance of rutin (standard)

\subsection{Determination of the Antibacterial and Antifungal Sensitivity and/or Resistance Profiles}

To determine the sensitivity and / or resistance profile of the bacterial and fungal strains, the disk-diffusion method was performed in solid medium [10]. The bacterial and fungal suspensions were seeded in petri dishes containing NA and SDA media, respectively. Then, disks soaked with $10 \mu \mathrm{L}$ of hex or AcOEt extract, solubilized in DMSO, and $\mathrm{MeOH}$ extract solubilized in sterile distilled water, were deposited on the surface of the bacterial and fungal culture media. The systems were incubated at $35 \pm 2{ }^{\circ} \mathrm{C}$ for $24 \mathrm{~h}$ for bacteria, and at $28 \pm 2{ }^{\circ} \mathrm{C}$ for $48 \mathrm{~h}$ for the fungus. The tests were performed in triplicate, and the results were expressed by the arithmetic mean of the obtained inhibition halos. 


\subsection{Determination of Minimum Inhibitory Concentration (MIC) and Minimum Microbicide Concentration (MMC)}

The MIC of the extracts in the strains used was determined by the broth microdilution method where $90 \mu \mathrm{L}$ of Muller Hinton Broth $(\mathrm{CMH})$ were transferred to the wells of a 96-well microdilution plate with U-shaped bottom [17, 18]. Then, $90 \mu \mathrm{L}$ of the product emulsion were inoculated from the third column of the plate (A3). Serial dilutions were performed, where an aliquot of $90 \mu \mathrm{L}$ was removed from the most concentrated well for the next, producing concentrations of $0.03 \mathrm{mg} / \mathrm{mL}$ in the last column (A12). Finally, $10 \mu \mathrm{L}$ of bacterial or fungal suspensions were added to each well. At the same time, controls were made for bacterial and fungal viability for susceptibility. As positive control we used erythromycin for bacteria, and nystatin for yeast. The plates were incubated at $35 \pm 2{ }^{\circ} \mathrm{C}$ for $24 \mathrm{~h}$ for bacteria, and $28 \pm 2{ }^{\circ} \mathrm{C}$ for $48 \mathrm{~h}$ for the fungal strain. After that time, $30 \mu \mathrm{L}$ of rezasurin $(0.1 \mathrm{mg} / \mathrm{mL})$ was added for quantitative analysis of microbial growth in the wells and determination of antimicrobial activity relative. To determine the MMC, aliquots of $5 \mu \mathrm{L}$ of the concentrations of the extracts that presented MIC were subcultured in Petri dishes containing CMH. After $24 \mathrm{~h}$ of incubation for bacteria $\left(35 \pm 2{ }^{\circ} \mathrm{C}\right)$ and $48 \mathrm{~h}$ for the fungus $\left(28 \pm 2{ }^{\circ} \mathrm{C}\right)$, a reading was performed to assess the MMC based on the controls. MMC was defined as the lowest concentration of the product capable of inhibiting bacterial and fungal growth or allowing the growth of less than three CFU, resulting in a $99.9 \%$ bactericidal and fungicidal activity [19]. The tests were performed in duplicate and the results expressed by the arithmetic mean of the MIC and MMC.

\subsection{Statistical Analysis}

All the results were evaluated by the Scott-Knott test of the SISVAR statistics software. The difference was considered significant at $\mathrm{P}<0.05$, and the data were presented with means \pm standard deviations (SD).

\section{RESULTS AND DISCUSSION}

\subsection{Phytochemical profile}

The preliminary phytochemical profile of Hex, AcOEt and $\mathrm{MeOH}$ extracts of $C$. argentea leaves revealed the presence of different compounds (Table 1). We identified steroids and triterpenes in Hex extract; flavonoids and tannins in $\mathrm{MeOH}$. In contrast, the AcOEt extract presented four of the nine compounds analyzed, coumarin, flavonoids, tannins and triterpenes.

Table 1. Preliminary phytochemical profile of Hex, AcOEt and MeOH extracts of Celosia argentea leaves. (-) absent; (+) present; Hex: hexane extract; AcOEt: ethyl acetate extract; $\mathrm{MeOH:} \mathrm{methanolic} \mathrm{extract.}$

\begin{tabular}{cccc}
\hline Class & \multicolumn{3}{c}{ Extract } \\
\cline { 2 - 4 } & Hex & AcOEt & MeOH \\
\hline Alkaloids & - & - & - \\
Quinones & - & - & - \\
Coumarins & - & + & - \\
Steroids & + & - & - \\
Flavonoids & - & + & + \\
Tannins & - & + & + \\
Triterpenes & + & + & - \\
Saponins & - & - & - \\
\hline
\end{tabular}

Two researches working with specimens of the same species, but collected in different places in India, identified alkaloids and saponins in methanolic extract [20,21], which does not occur in our work. This difference can be explained by the diversity of defense mechanisms that 
plants have, since the choices of various secondary metabolites are dependent on growing conditions and this is invariably influenced by the plant's metabolic pathways [22], which allows them to deal with different stress conditions.

High temperatures, for example, increase the biosynthesis of alkaloids [23], which was identified in the methanol extract of these works, as the temperatures at the collection sites range from 30.8 to 43.3 , and here from $22^{\circ} \mathrm{C}$ to $31^{\circ} \mathrm{C}$.

Quantitative analysis of $C$. argentea extracts for the presence of phenolic compounds, flavonoids and tannins are shown in Table 2.

Table 2. Quantitative analysis of Celosia argentea leaves extracts for the presence of phenolic compounds, flavonoids and tannins. AcOEt: ethyl acetate extract; $\mathrm{MeOH}$ : methanolic extract. Means followed by lowercase letters horizontally in each column differ by the Scott-Knott test at the 5\% level.

\begin{tabular}{cccc}
\hline Extract & Phenolics $(\mathbf{m g ~ G A E} / \mathbf{g})$ & Flavonoids $(\mathbf{m g ~ R E} / \mathbf{g})$ & Tannins $(\mathbf{m g}$ TAE$/ \mathbf{g})$ \\
\hline AcOEt & $252.02 \pm 0.02^{\mathrm{a}}$ & $234.25 \pm 0.01^{\mathrm{a}}$ & $47.17 \pm 0.008^{\mathrm{b}}$ \\
$\mathbf{M e O H}$ & $145.44 \pm 0.01^{\mathrm{b}}$ & $68.0 \pm 0.002^{\mathrm{b}}$ & $103.72 \pm 0.004^{\mathrm{a}}$ \\
\hline
\end{tabular}

From these results we can be inferred that the ethyl acetate extract had a higher content of total phenolics when compared to the methanol extract, and this is mainly due to the high concentration of flavonoids present in the ethyl acetate extract. The ethyl acetate extract showed the highest content of total flavonoids. This may be due to the presence of a higher concentration in the non-polar flavonoids ethyl acetate extract. Through the results presented, it is possible to infer that the ethyl acetate extract (AcOEt) had lower total tannin content when compared to the methanol extract.

Thus, ethyl acetate is effective in extracting a greater amount of phenolics and flavonoids from plants compared to methanol, whereas methanol proved to be more efficient in extracting tannins.

The presence of flavonoids in the AcOEt and $\mathrm{MeOH}$ extracts can favor biological activities, including antimicrobial, anti-inflammatory, antitumor, in addition to assisting in the treatment of neurodegenerative diseases [24]. Flavonoids are widely known to exert an antioxidant function and inhibit lipid peroxidation, so the presence of this metabolite may be the scientific basis for the popular use of $C$. argentea in the treatment of skin diseases, dysentery and inflammation [25].

The prolonged and indiscriminate pharmacological therapy has increased the search for new medicinal alternatives. Thus, the use of herbal medicines appears in the perspective of reducing treatment costs, minimizing side effects and avoiding excessive consumption of synthetic drugs [24].

Malomo et al. (2011) [26] identified high concentrations of phenolic compounds (3.26\%) and flavonoids (2.38\%) in the aqueous extract of the leaves of $C$. argentea, and correlated the presence of these constituents with the antioxidant properties of the plant, data that are correlated to those described in this article.

\subsection{Determination of the Antibacterial and Antifungal Sensitivity and / or Resistance Profile}

The results of the susceptibility test for the extracts of $C$. argentea against bacterial and fungal strains were determined by the disk-diffusion assay in solid medium (Table 3 ). 
Table 3. Inhibition halos in millimeters $(\mathrm{mm})$ of Celosia argentea extracts against bacterial and fungal strains. ND: Not detected; Hex: hexane extract; AcOEt: ethyl acetate extract; MeOH: methanolic extract.

\begin{tabular}{cccc}
\hline \multirow{2}{*}{ Strain } & \multicolumn{3}{c}{ Extract } \\
\cline { 2 - 4 } & Hex & AcOEt & MeOH \\
\hline S. aureus & ND & $9.7 \pm 0.6 \mathrm{~nm}$ & $19.7 \pm 0.6 \mathrm{~nm}$ \\
M. luteus & ND & $13.3 \pm 0.6 \mathrm{~nm}$ & $24.7 \pm 0.6 \mathrm{~nm}$ \\
B. subtilis & ND & $12.3 \pm 0.6 \mathrm{~nm}$ & $10.0 \pm 1.0 \mathrm{~nm}$ \\
E. faecalis & ND & ND & ND \\
$\boldsymbol{P}$. aeruginosa & ND & ND & $13.0 \pm 1.0 \mathrm{~mm}$ \\
E. coli & ND & ND & ND \\
S. Marcencens & ND & ND & ND \\
M. smegmatis & ND & ND & $24.7 \pm 0.6$ \\
C. Albicans & ND & ND & $20.7 \pm 1.2$ \\
\hline
\end{tabular}

When the parameters of susceptibility and/or resistance of the Hex, AcOEt and $\mathrm{MeOH}$ extracts were analyzed, we found the last one was more effective, showing inhibition against $M$. luteus, M. smegmatis and C. albicans. In contrast, B. subtilis and P. aeruginosa were resistant to $\mathrm{MeOH}$ extract, with inhibition halo of $10.0 \pm 1.0 \mathrm{~mm}$ and $13.0 \pm 1.0 \mathrm{~mm}$ respectively. For the AcOEt extract, $S$. aureus, M. luteus and B. subtilis were resistant, with inhibition zone of less than $14 \mathrm{~mm}$, in addition, all other strains tested against this extract showed no activity, a phenomenon also seen in the test with Hex extract, where it was not possible to visualize inhibition activity of any tested microorganism.

The resistance of Gram-negative bacteria to extracts of $C$. argentea leaves may be due to the structural machinery of these pathogens, which includes the outer lipopolysaccharide membrane, cell wall and the inner membrane. This one is generally absent in Gram-positive and serves as a pharmacological barrier, preventing the entry of antibiotics [27]. An evaluation of the antibacterial and antifungal effects of methanolic and chloroform extract from the stem and root of $C$. argentea and inferred that only the chloroform extract was effective against $S$. aureus, and none showed any significant effect against the strains of $C$. albicans and Aspergillus niger [28], a result that is opposed to those obtained in this study, since the strain of C. albicans was sensitive $(20.7 \pm 1.2 \mathrm{~mm})$ to the $\mathrm{MeOH}$ extract.

\subsection{Determination of Minimum Inhibitory Concentration (MIC) and Minimum Microbicide Concentration (MMC)}

The result of the antibacterial and antifungal activities of $\mathrm{Hex}$, AcOEt and $\mathrm{MeOH}$ extracts of C. argentea leaves was determined by MIC and MMC using the broth microdilution technique. MIC values ranged from 0.06 to $2 \mathrm{mg} / \mathrm{mL}$ (Table 4). The most significant antimicrobial effect was shown by the extract AcOEt against the strain of M. luteus, with MIC of $0.06 \mathrm{mg} / \mathrm{mL}$ and MMC of $0.25 \mathrm{mg} / \mathrm{mL}$. For the $\mathrm{MeOH}$ extract, the strains of M. luteus and M. smegmatis presented MIC of $0.25 \mathrm{mg} / \mathrm{mL}$, as well as MMC. However, Hex extract was less effective, for M. smegmatis and C. albicans the MIC and MMC was $1 \mathrm{mg} / \mathrm{mL}$ and $2 \mathrm{mg} / \mathrm{mL}$ in respective.

Table 4. Minimum Inhibitory Concentration and Minimum Microbic Concentration of Celosia argentea leaves extracts. MIC: Minimum Inhibitory Concentration; MMC: Minimum Microbic Concentration; Hex: hexane extract; AcOEt: ethyl acetate extract; $\mathrm{MeOH}$ : methanolic extract.

\begin{tabular}{ccccccc}
\hline \multirow{2}{*}{ Strain } & \multicolumn{7}{c}{ Extract } \\
\cline { 2 - 7 } & \multicolumn{2}{c}{ Hex $(\mathbf{m g} / \mathbf{m L})$} & \multicolumn{2}{c}{ AcOEt $(\mathbf{m g} / \mathbf{m L})$} & \multicolumn{2}{c}{ MeOH $(\mathbf{m g} / \mathbf{m L})$} \\
\hline SIC & MMC & MIC & MMC & MIC & MMC \\
\hline M. luteus & 1 & 8 & 0.5 & 8 & 0.25 & 2 \\
B. subtilis & 2 & 8 & 0.06 & 0.25 & 0.25 & 0.25 \\
P. aeruginosa & 1 & 16 & 0.25 & 0.25 & 2 & 2 \\
M. smegmatis & 2 & 8 & 1 & 2 & 0.5 & 1 \\
C. Albicans & 1 & 2 & 0.5 & 1 & 0.25 & 0.25 \\
\end{tabular}


MIC may vary according to the sensitivity of the microorganism species [29], a notoriety analyzed between the M. luteus and B. subtilis strains compared to the $\mathrm{MeOH}$ extract, since the latter was less susceptible to the concentration of the extract ( $2 \mathrm{mg} / \mathrm{mL}$ MIC and MMC). A product has a bactericidal property when the MIC / MMC ratio is between 1 and 2, an effect capable of causing the eventual microorganism death [30]. Therefore, the Hex extract was bactericidal and fungicidal for $M$. smegmatis and $C$. albicans, added to these the AcOEt had significant action against $P$. aeruginosa, and the $\mathrm{MeOH}$ extract was bactericidal and fungicidal against all strains tested, with the exception of $S$. aureus.

According to several authors in microbiology, including Rios and Recio (2005) [31], an extract can be considered promising for future research studies when it is active at a concentration lower than $0.1 \mathrm{mg} / \mathrm{mL}$.

\subsection{Diphenyl-1-picrilhidrazil (DPPH) sequestering activity and determination of reducing power}

The DPPH radical reduction capacity of Hex, AcOEt and $\mathrm{MeOH}$ extracts of $C$. argentea leaves was determined by the decrease in absorbance at $517 \mathrm{~nm}$, summarized in Table 6 . The $\mathrm{MeOH}$ extract exhibited greater capacity to eliminate the DPPH radical $(70.4 \mathrm{~nm} \pm 0.03 \%)$, when compared to AcOEt $(9.8 \pm 0.001 \%)$. The values of the antioxidant tests for the Hex extract were not statistically significant, and therefore, we did not include it in this study.

The results of the reducing power are exposed in Table 5, where the AcOEt extract showed greater reducing activity $(289.23 \pm 0.05 \mathrm{mg} \mathrm{AA} / \mathrm{g})$ when compared to the $\mathrm{MeOH}$ extract $(181.51 \pm 0.03)$.

Table 5. Antioxidant activity of Celosia argentea extracts by DPPH and reducing power. AcOEt: ethyl acetate extract; $\mathrm{MeOH}$ : methanolic extract. Means followed by lowercase letters horizontally in each column differ by the Scott-Knott test at the $5 \%$ level.

\begin{tabular}{ccc}
\hline Extract & Reducing power $(\mathbf{m g ~ A A} / \mathbf{g})$ & DPPH $(\%)$ \\
\hline AcOEt & $289.23 \pm 0.05^{\mathrm{a}}$ & $9.8 \pm 0.001^{\mathrm{a}}$ \\
MeOH & $181.51 \pm 0.03^{\mathrm{b}}$ & $70.4 \pm 0.03^{\mathrm{b}}$ \\
Ascorbic acid & $460.68 \pm 0.05$ & $460.68 \pm 0.05$ \\
\hline
\end{tabular}

The polarity of the solvents is related to greater extraction of bioactive compounds, thus contributing to the antioxidant activity, this is due in part to the release of phenolic and flavonoid compounds present in the methanolic extract [32]. However, although the AcEOt extract has higher concentrations of phenolics and flavonoids, as shown in this study, variations in the water-solvent ratio can modify the solubilities of the phytochemicals and, therefore, alter the DPPH radical elimination property in the AcEOt extract [33].

Literature described that elimination of the DPPH radical from the aqueous extract of $C$. argentea is dose-dependent, with a significant effect on the $1 \mathrm{mg} / \mathrm{mL}$ concentration, demonstrating an approximate antioxidant effect of $\pm 80 \%$ [28], values higher than those analyzed in this study, since $270 \mu \mathrm{L}$ of $\mathrm{MeOH}$ extract was able to eliminate $50 \%$ of DPPH radicals.

The reducing activity of the extracts of $C$. argentea leaves was carried out by the method of reducing power, in which the increase in the absorbance of the mixture indicates greater reducing power of the extracts. In this test, the presence of antioxidant compounds in the sample favors the reduction of $\mathrm{Fe}^{+3}$ in $\mathrm{Fe}^{+2}$, which can be monitored due to the production of a blue complex $\left(\mathrm{Fe}_{4}\left[\mathrm{Fe}(\mathrm{CN})_{6}\right]_{3}\right)$, which is favored by the potassium ferricyanide reagent [14].

\subsection{Total Antioxidant Capacity (TAC)}

In this method, the phosphate/molybdenum complex is formed at acidic $\mathrm{pH}$, and the subsequent reduction of molybdenum (VI) to molybdenum (V) by the plant extract. It was 
observed that the antioxidant capacity of $C$. argentea leaf extracts ranged from $34.93 \%$ to $89.6 \%$ (Table 6). The results revealed that the AcOEt extract showed greater antioxidant activity than the $\mathrm{MeOH}$ extract at the same concentration.

Table 6. Antioxidant activity of Celosia argentea extracts by Total Antioxidant Capacity method. Hex: hexane extract; AcOEt: ethyl acetate extract; $\mathrm{MeOH}$ : methanolic extract. Means followed by lowercase letters horizontally in each column differ by the Scott-Knott test at the $5 \%$ level.

\begin{tabular}{ccc}
\hline CONCENTRATIONS & AcOEt & MeOH \\
\hline $125 \mu \mathrm{g} / \mathrm{mL}$ & $80.27 \%^{\mathrm{a}}$ & $34.93 \%^{\mathrm{b}}$ \\
$250 \mu \mathrm{g} / \mathrm{mL}$ & $89.60 \%^{\mathrm{a}}$ & $38.40 \%^{\mathrm{b}}$ \\
$500 \mu \mathrm{g} / \mathrm{mL}$ & $117.10 \%^{\mathrm{a}}$ & $47.20 \%^{\mathrm{a}}$ \\
\hline
\end{tabular}

The reducing power of aqueous extract of $C$. argentea leaves in another work, however, the effective concentration of the product was $100 \mathrm{mg} / \mathrm{mL}$, a dose higher than that one tested in this study. The authors suggest that the reducing action of $C$. argentea leaves may be related to the reduction of the transition state of iron ions and, consequently, in the release of superoxide radicals generated from the metal, in addition to the phenolic content present in the sample [26], condition which favors the findings of the present study, since both extracts showed satisfactory results.

Like our finding, Zengin and Aktumsek (2014) [34] found that acetone extracts had greater activity than methanolic extracts, and this effect may be related to the high content of antioxidant components, especially phenolic ones.

\section{CONCLUSION}

The phytochemical screening of vegetables is useful for the standardization of medicines, aiding in their safety. Hex, AcOEt and $\mathrm{MeOH}$ extracts from $C$. argentea leaves contain steroids, triterpenes, flavonoids, tannins and coumarins, proving that the plant is an efficient reservoir of bioactive compounds, which add medicinal values to the species. In addition, the tested products showed bactericidal and fungicidal activities on the strains of $M$. smegmatis, $C$. Albicans, $P$. aeruginosa, with emphasis on the $\mathrm{MeOH}$ extract, effective for most microorganisms, except for $S$. aureus. The antioxidant activity of $C$. argentea reported in the present study shows that the vegetable has the potential to prevent and / or manage conditions caused by oxidative stress. Therefore, $C$. argentea can be a potential antibacterial and antioxidant agent, however, further investigations about its pharmacological properties in vitro and in vivo are necessary.

\section{CONFLICT OF INTEREST}

The authors declare no conflicts of interest.

\section{REFERENCES}

1. Salesse D, Medeiros FC, Da Silva CCM, Lourenço ELB, Jacomassi E. Etnobotânica e Etnofarmacologia das espécies de Amaryllidaceae, Anacardiaceae, Annonaceae e Apiaceae. Arq Ciênc Saúde. 2018;22(3):205-16. doi: 10.25110/arqsaude.v22i3.2018.6376

2. Bhorga PH, Kamle S. Comparative phytochemical investigation and determination of total phenols and flavonoid concentration in leaves and flowers extract of Delonix regia (Boj. Ex. Hook). J Drug Deliv. 2019;9(4-s):1034-37. doi: 10.22270/jddt.v9i4-s.3761

3. Saritha P, Sreeramulu A. Allelopathic effects of Celosia argentea L. leaf extracts on crop plant seed germination. Int. J Life Sci Biotechnol Pharma Res. 2013;2(1):1-11.

4. CNCFlora. Celosia grandifolia in Lista Vermelha da flora brasileira versão 2012.2 Centro Nacional de Conservação da Flora [Internet]. Rio de Janeiro (RJ): Instituto de Pesquisas Jardim Botânico do Rio de Janeiro; 2012 Apr 04 [cited 2021 Apr 15]. Avaiable from: http://cncflora.jbrj.gov.br/portal/pt$\mathrm{br} /$ profile/Celosia grandifolia 
5. Eckstein B, Bedendo IP. Detecção molecular de fitoplasma em planta do gênero Celosia com malformação das folhas. Summa Phytopatologica. 2010;36(1):89. doi: 10.1590/S010054052010000100017

6. Vaishnav J, Subha V, Kirubanandan S, Arulmozhi M, Renganathan S. Green synthesis of zinc oxide nanoparticles by Celosia argentea and its characterization. J Optoelectron Biomed Mater. 2017;9(1):59-71.

7. Hase K, Kadota S, Basnet P, Namba T, Takahashi T. Hepatoprotective effects of traditional medicines. Isolation of the active constituent from seeds of Celosia argentea. Phytother Res. 1996;10(5):387-92. doi: 10.1002/(SICI)1099-1573(199608)10:5<387::AID-PTR856>3.0.CO;2-V

8. Gnanamani A, Priya KS, Radhakrishnan N, Babu M. Antibacterial activity of two plant extracts on eight burn pathogens. J Ethnopharmacol 2003;86(1):59-61. doi: 10.1016/s0378-8741(03)00044-8

9. Tang Y, Xin HL, Guo ML. Review on research of the phytochemistry and pharmacological activities of Celosia argentea. Rev Bras Farmacogn. 2016;26(6):787-96. doi: 10.1016/j.bjp.2016.06.001

10. Koneman EW, Allen SD, Janda WM, Schreckenberger PC, Win WCJ. Diagnóstico microbiológico. 6. ed. São Paulo: Médica e Científica Ltda; 2008.

11. Ostrosky EA, Mizumoto MK, Lima MEL, Kaneko TM, Nishikawa SO, Freitas BR. Métodos para avaliação da atividade antimicrobiana de determinação de concentração mínima inibitória (CMI) de plantas medicinais. Rev Bras Farmacogn. 2008;18(2):301-307. doi: 10.1590/S0102695X2008000200026

12. Wagner H, Bladt S. Plant drug analysis: a thin layer chromatography atlas. 2. ed. Nova York (US): Springer; 2001.

13. Waksmundzka-Hajnos M, Sherma J, Kowalska T. Thin layer chromatography in Phytochemistry. 1. ed. Nova York (US): CRC Press; 2008.

14. Waterman PG, Mole S. Analysis of phenolic plant metabolites. 1. ed. Oxford (GB): Blackwell Scientific Publications; 1994.

15. Barroso MF, Noronha JP, Delerue-Matos C, Oliveira MBPP. Flavored waters: influence of ingredients on antioxidant capacity and terpenoid profile by HS-SPME/ GC-MS. J Agric Food Chem. 2011;59:5062-72. doi: 10.1021/jf1048244

16. Shad MA, Haq N, Tanzila R, Ahmad HB, Mazhar H. Optimization of extraction efficiency of tannins from Cichoriumintybus L.: Application of response surface methodology. J Med Plant Res. 2012;28(6):4467-74. doi: 10.13140/2.1.3761.7283

17. Viljoen A, van Vuuren S, Ernst E, Klepser M, Demirci B, Başer H, et al. Osmitopsis asteriscoides (Asteraceae) the antimicrobial activity and essential oil composition of a Cape-Dutch remedy. J Ethnopharmacol. 2003;88(2):137-143. doi: 10.1016/S0378-8741(03)00191-0

18. Şahin F, Güllüce M, Daferera D, Sökmen A, Sökmen M, Polissiou M, et al. Biological activities of the essential oils and methanol extract of Origanumvulgare ssp. vulgare in the Eastern Anatolia region of Turkey. Food Control. 2004;15(7):549-57. doi: 10.1016/j.foodcont.2003.08.009

19. Ingroff AE, Chaturvedi V, Fothergill A, Rinaldi MG. Optimal testing conditions for determining MICs and minimum fungicidal concentrations of new and established antifungal agents for uncommon molds: NCCLS collaborative study. J Clin Microbiol. 2002;40(10):3776-81. doi: 10.1128/JCM.40.10.3776-3781.2002

20. Fayaz M, Bhat MH, Kumar A, Jain AK. Phytochemical screening and nutritional analysis of some parts of Celosia argentea L. Chem. 2019;8(1):12-9. doi: 10.7598/cst2019.1561

21. Preety J, Saranya VT. Phytochemical analysis on leaf extract of Celosia argentea land its efficacy of antioxidant and anti bacterial activity. Int J Pharmtech Res. 2015;8(4):1-6.

22. Akula R, Ravishankar GA. Influence of abiotic stress signals on secondary metabolites in plants. Plant Signal Behavi. 2011;6(11):1720-31. doi: 10.4161/psb.6.11.17613

23. Jan R, Asaf S, Numan M, Kim KM. Plant secondary metabolite biosynthesis and transcriptional regulation in response to biotic and abiotic stress conditions. Agronomy. 2021;11(5):1-31. doi: 10.3390/agronomy11050968

24. Tolouei AE, Dülger N, Ghatee R, Kennedy S. A magnetically responsive biomaterial system for flexibly regulating the duration between pro-and anti-inflammatory cytokine deliveries. Adv Healthc Mater. 2018;7(12):1-7. doi: 10.1002/adhm.201800227

25. Tsuchiya H. Structure-dependent membrane interaction of flavonoids associated with their bioactivity. Food Chem. 2010;120(4):1089-96. doi: 10.1016/j.foodchem.2009.11.057

26. Malomo SO, Ore A, Yakubu MT. In vitro and in vivo antioxidant activities of the aqueous extract of Celosia argentea leaves. Indian J Pharmacol. 2011;43(3):278. doi: 10.4103/0253-7613.81519

27. Exner M, Bhattacharya S, Christiansen B, Gebel J, Goroncy-Bermes P, Hartemann P, et al. Antibiotic resistance: What is so special about multidrug-resistant Gram-negative bacteria? GMS Hyg Infec Control. 2017;12:1-24. doi: 10.3205/dgkh000290 
28. Sreevani B, Patil RS, Kammar M. Antimicrobial activity of Celosia argentea L. in the Hyderabad Karnataka region. J Pharmacogn Phytochem. 2018;7(5):2041-47.

29. Araújo MIF, Freitas FOR, Morais AMB, Brustein VP, Nogueira TBSS, Nogueira RBSS, et al. 2018. Antifungal activity and in silico toxicology of the O-Eugenol. IJPPR. 2018;10(7):284-90. doi: 10.25258/PHYTO.10.7.3

30. Hafidh RR, Abdulamir AS, Vern LS, Bakar FA, Abas F, Jahanshiri F, et al. Inhibition of growth of highly resistant bacterial and fungal pathogens by a natural product. Open Microbiol J. 2011;5(1):96106. doi: $10.2174 / 1874285801105010096$

31. Rios JL, Recio MC. Medicinal plants and antimicrobial activity. J Ethnopharmacol. 2005;100(1-2):804.

32. Rahaiee S, Moini S, Hashemi M, Shojaosadati SA. Evaluation of antioxidant activities of bioactive compounds and various extracts obtained from saffron (Crocus sativus L.): a review. J Food Sci Tech Mys. 2015;52(4):1881-88. doi: 10.1007/s13197-013-1238-x

33. D'Alessandro LG, Kriaa K, Nikov I, Dimitrov K. Ultrasound assisted extraction of polyphenols from black chokeberry. Sep Purif Methods. 2012;93(1):42-7. doi: 10.1016/j.seppur.2012.03.024

34.Zengin G, Aktumsek A. Investigation of antioxidant potentials of solvent extracts from different anatomical parts of Asphodeline anatolica E. Tuzlaci: An endemic plant to Turkey. Afr J Tradit Complement Altern Med. 2014;11(2):481-8. doi: 10.4314/ajtcam.v11i2.37 